\title{
大型構造用鋼管の力学的特性，残留応力，及び寸法精度 MECHANICAL PROPERTIES, RESIDUAL STRESSES AND DIMENSIONAL ACCURACIES OF LARGE-SIZE CIRCULAR STRUCTURAL STEEL TUBES
}

\author{
桑 村 仁* \\ Hitoshi KUWAMURA
}

\begin{abstract}
Mechanical properties, residual stresses and dimensional accuracies of large-size structural steel tubes of circular hollow section designated as STK400 and STKN490B were investigated. The sample number was 18 as delivered, and half cuts of them were normalized. As-delivered tubes exhibited higher yield strength, tensile strength and yield ratio, but less uniform elongation than their correspondent normalized ones. Charpy absorbed energy of as-delivered was smaller in circumferential direction than in longitudinal direction, the tendency of which was not altered in the normalized. Residual stresses in ERW tubes in their longitudinal direction were extremely large in comparison with UO-forming tubes and Bending-roll tubes. Dimensional deviations from nominal sizes were small enough to satisfy the JIS tolerances, but not always met European Standards.
\end{abstract}

Keywords : Structural steel tube, Circular hollow section, Mechanical properties, Residual stresses, Dimensional accuracies 構造用鋼管，円形中空断面，力学的特性，残留応力，寸法精度

\section{1. 序}

本論文は比較的厚肉で大径の構造用鋼管を建築鉄骨に使用する際 に必要となる設計施工上の様々な特性值の実態を調査したものであ る。調查対象は一般構造用炭素鋼鋼管 STK(JIS G 3444) と建築構造 用炭素鋼鋼管 STKN(JIS G 3475) であり, 形状は円形中空断面 (CHS)である。昨今の建築鉄骨では鋼管よりも角形鋼管が多く用い られているので，混同を避ける必要があるときは鋼管を円形鋼管と 呼ぶこととし，そうでない場合は JIS にならって単に鋼管と呼ぶこ とにする。

建築における円形鋼管は国内外ともトラス構造に用いられること が多く, 鋼管構造というと通常, 鋼管トラスが想起される。円形鋼 管がラーメン構造の柱材として用いられることは比較的少なく, 特 に，我が国では角形鋼管が鉄骨ラーメン柱の大勢を占めている。し かしながら, 円形鋼管は同断面積・同厚の正方形角形鋼管と比べる と, Table 1 に示すように, 断面性能が総じて優れている。断面 2 次モーメント, 断面 2 次半径, 塑性断面係数が相対的に大きいこと は, 剛性, 座屈耐力, 保有水平耐力の面で円形鋼管のほうが構造設 計上，有利であることを意味している。円形断面が完全な軸対称断 面でその性能が方向に依らないことや曲面がもつ意匠性も魅力とさ れている。

にもかかわらず，円形鋼管が敬遠される最大の理由は価格の問題 である。Fig. 1 に過去 7 年ほどの円形鋼管と角形鋼管の月次販売価
Table 1 同断面積 - 同厚の円形鋼管と角形鋼管の断面性能比

\begin{tabular}{|c|c|}
\hline 断面特性 & 円形 /角形 \\
\hline $\begin{array}{l}\text { 任意の図心軸に関する断面2次モー } \\
\text { メント }\left(I_{x}, I_{y}, I_{45}\right)\end{array}$ & $1.07 \sim 1.20(1.22)$ \\
\hline $\begin{array}{l}\text { 任意の図心軸に関する断面2次半径 } \\
\left(i_{x}, i_{y}, i_{45}\right)\end{array}$ & $1.03 \sim 1.09(1.10)$ \\
\hline $\begin{array}{l}x \text { 軸または } y \text { 軸に関する弾性断面係 } \\
\text { 数 }\left(Z_{e x}, Z_{e y}\right)\end{array}$ & $0.94 \sim 0.95(0.95)$ \\
\hline $\begin{array}{l}\text { 対角軸に関する弾性断面係数 } \\
\left(Z_{e 45}\right)\end{array}$ & $1.13 \sim 1.32(1.35)$ \\
\hline $\begin{array}{l}x \text { 軸または } y \text { 軸に関する塑性断面係 } \\
\text { 数 }\left(Z_{p x}, Z_{p y}\right)\end{array}$ & $1.02 \sim 1.07(1.08)$ \\
\hline $\begin{array}{l}\text { 対角軸に関する塑性断面係数 } \\
\left(Z_{p 45}\right)\end{array}$ & $1.05 \sim 1.14(1.15)$ \\
\hline サン・ブナンねじり定数 $\left(J_{T}\right)$ & $1.15 \sim 1.56(1.62)$ \\
\hline 外周長 $(\varphi)$ & $1.00(1-0.215 t / B)$ \\
\hline 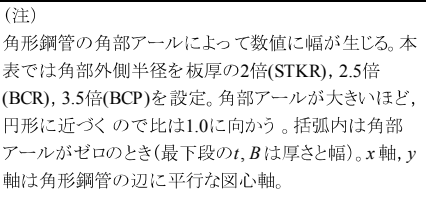 & $B$ \\
\hline
\end{tabular}

格 1)の推移を示す。引張強さ $400 \mathrm{MPa}$ のやや大型サイズ（外寸 $400 \mathrm{~mm} \times$ 厚さ $16 \mathrm{~mm}$ ） では角形鋼管 STKR400 に対して円形鋼管 STK400 の価格は 1.15 1.72 倍 (調査期閒平均で 1.46 倍) である。

\footnotetext{
* 東京大学大学院工学系研究科建築学専攻 教授 $\cdot$ Ph. D.

Prof., Dept. of Architecture, School of Engineering, The University of Tokyo, Ph. D.
} 


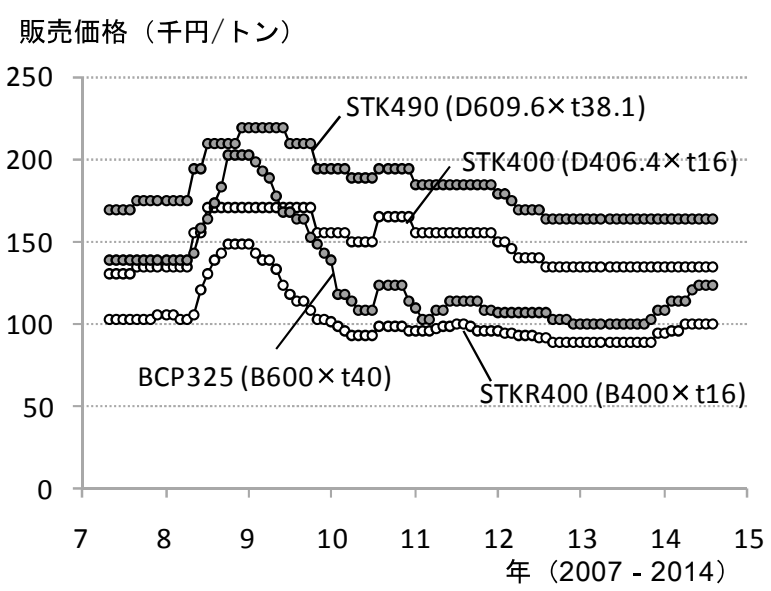

Fig.1 円形鋼管と角形鋼管の販売価格の推移

引張強さ $490 \mathrm{MPa}$ の大型サイズ（外寸 $600 \mathrm{~mm} \times$ 厚さ $40 \mathrm{~mm}$ ）でみ ると，角形鋼管 BCP325（大臣認定品）に対して円形鋼管 STK490 の価格は $1.03 \sim 1.79$ 倍（平均で 1.47 倍）である。この価格比率は 上で述べた断面性能の比を上回っており, 円形鋼管が角形鋼管に比 ぶて競争力の点で劣っていることを物語っている。

価格の問題は構造工学では如何ともし難いが, 円形鋼管のもつ構 造的利点は捨てがたいものがある。今後, 円形鋼管が角形鋼管と同 様, 鉄骨ラーメン柱のもう一つの選択肢として普及する場合に備え， 柱材として想定される比較的厚肉で大径の円形鋼管の各種特性を調 查した。調査項目は, 力学的特性 (応力 -ひずみ特性とシャルピー 衝撃特性), 残留応力, 寸法精度である。今まで, この種の系統的調 查研究は行われておらず, 鋼管構造の実験的研究に付随して鋼管の 応力ーひず夕特性が断片的に調べられてきたにすぎない。シャルピ 一衝撃特性と寸法精度に関する公開データは皆無といってよい。残 留応力については薄肉小径の電縫鋼管を対象としたもの 2), 3), 4)が有
るのみである。

\section{2. 試験に用いた鋼管}

試験に用いた鋼管は市中から購入した 18 本で，そのミルシート 值を Table 2 に示す。厚さの小さいほうから順に並心゙，同厚のもの は外径の小さいほうから並べて, No.1〜18 の試験体番号を付けて ある。外径 $D$ と厚さ $t$ の組合せを実測值でプロットしたのが Fig.2 で, 径厚比 $D / t$ は 10〜35 の範囲にある。18 本の鋼管は STKN490B-E-G, STK400-E-G, STK400-A(UO), STK400-A(Bend)+SR の 4 グルー プに分けられ，それぞれ 3 本， 7 本，4 本，4 本である。記号の意味 は Table 2 の下注に記したが, 以下でも補足説明する。厚さ，外径， 製造方法の種類を確保することに配慮したため，結果的に 4 社の製 品が混在することとなった。18 本それぞれについて分光分析によっ て化学成分を調査し，ミルシートが実物と対応していることを確認 した。

購入品は各鋼管とも長さ $1 \mathrm{~m}$ で，寸法精度に関する測定を行った

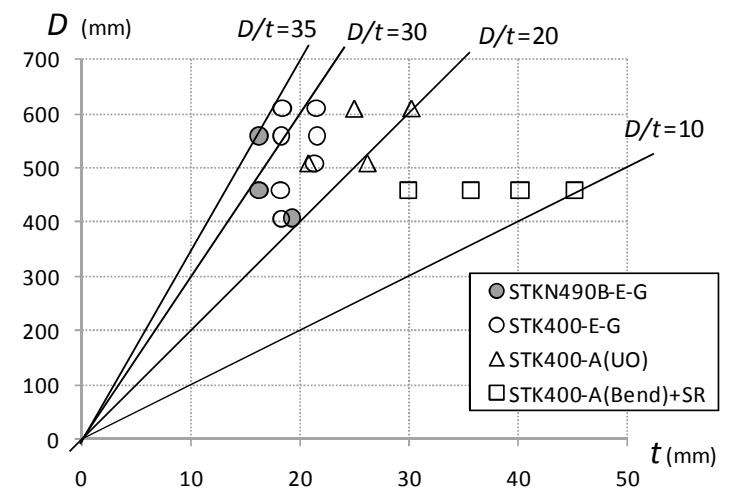

Fig.2＼cjkstart試験に用いた鋼管の外径と厚さの組合せ

Table 2 試験に用いた鋼管のミルシート值

\begin{tabular}{|c|c|c|c|c|c|c|c|c|c|c|c|c|c|c|c|c|c|}
\hline \multirow[b]{2}{*}{$\begin{array}{l}\text { 試騟体 } \\
\text { 番号 } \\
\text { No. }\end{array}$} & \multirow[b]{2}{*}{ 規格 ${ }^{* 1}$} & \multirow[b]{2}{*}{ 製造方法 ${ }^{* 2}$} & \multirow[b]{2}{*}{ メーカー ${ }^{*_{3}}$} & \multirow{2}{*}{$\begin{array}{c}\text { 公称寸法 } \\
D_{n} \times t_{n} \\
(\mathrm{~mm})\end{array}$} & \multicolumn{6}{|c|}{ 機械的性質 } & \multicolumn{7}{|c|}{ 化学成分 $(\%)$} \\
\hline & & & & & 引張試験片 ${ }^{* 4}$ & \begin{tabular}{|c|}
$\begin{array}{c}\text { 降伏点ま } \\
\text { たは耐力 } \\
* 5 \\
\left(\mathrm{~N} / \mathrm{mm}^{2}\right)\end{array}$ \\
\end{tabular} & $\begin{array}{c}\text { 引張強さ } \\
\\
\left(\mathrm{N} / \mathrm{mm}^{2}\right)\end{array}$ & $\begin{array}{c}\text { 降伏比 } \\
(\%)\end{array}$ & $\begin{array}{c}\text { 伸び } \\
(\%)\end{array}$ & 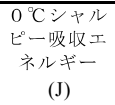 & $\mathrm{C}$ & $\mathrm{Si}$ & $\mathrm{Mn}$ & $\mathrm{P}$ & $\mathrm{S}$ & $\mathrm{N}$ & Ceq \\
\hline 1 & STKN490B & E-G & $A$ 社 & $457.2 \times 16.0$ & L方向, 12C号 & 459 & 548 & 84 & 43 & 190 & 0.15 & 0.16 & 0.81 & 0.013 & 0.004 & 0.0024 & 0.29 \\
\hline 2 & STKN490B & E-G & $A$ 社 & $558.8 \times 16.0$ & L方向, $12 \mathrm{C}$ 号 & 447 & 546 & 82 & 43 & 251 & 0.16 & 0.17 & 0.75 & 0.015 & 0.004 & 0.0020 & 0.29 \\
\hline 3 & STK 400 & E-G & B 社 & $406.4 \times 19.0$ & $\mathrm{~T}$ 方向, 5 号 & 336 & 465 & - & 40 & - & 0.16 & 0.02 & 0.83 & 0.013 & 0.002 & - & - \\
\hline 4 & STKN490B & E-G & $A$ 社 & $406.4 \times 19.0$ & L方向, 12B号 & 421 & 543 & 78 & 41 & 170 & 0.16 & 0.16 & 0.72 & 0.017 & 0.005 & 0.0026 & 0.29 \\
\hline 5 & STK400 & E-G & B社 & $457.2 \times 19.0$ & T方向, 5号 & 332 & 451 & - & 40 & - & 0.16 & 0.01 & 0.86 & 0.014 & 0.003 & - & - \\
\hline 6 & STK400 & E-G & B 社 & $558.8 \times 19.0$ & $\mathrm{~T}$ 方向, 5 号 & 358 & 475 & - & 43 & - & 0.10 & 0.01 & 0.66 & 0.012 & 0.003 & - & - \\
\hline 7 & STK400 & E-G & $A$ 社 & $609.6 \times 19.0$ & $\mathrm{~T}$ 方向, 5号 & 326 & 462 & - & 47 & - & 0.16 & 0.01 & 0.95 & 0.019 & 0.006 & - & - \\
\hline 8 & STK400 & $\mathrm{A}(\mathrm{UO})$ & B社 & $508.0 \times 20.6$ & T方向, 5号 & 433 & 538 & - & 45 & - & 0.08 & 0.22 & 1.52 & 0.015 & 0.002 & - & - \\
\hline 9 & STK400 & E-G & $A$ 社 & $508.0 \times 22.0$ & T方向, 5号 & 353 & 467 & - & 47 & - & 0.16 & 0.03 & 0.93 & 0.017 & 0.004 & - & - \\
\hline 10 & STK400 & E-G & A社 & $558.8 \times 22.0$ & T方向, 5 号 & 319 & 452 & - & 52 & - & 0.16 & 0.02 & 0.92 & 0.014 & 0.004 & - & - \\
\hline 11 & STK400 & E-G & $A$ 社 & $609.6 \times 22.0$ & $\mathrm{~T}$ 方向, 5 号 & 343 & 455 & - & 47 & - & 0.16 & 0.02 & 0.93 & 0.018 & 0.005 & - & - \\
\hline 12 & STK400 & $\mathrm{A}(\mathrm{UO})$ & B社 & $609.6 \times 25.0$ & T方向, 5号 & 357 & 472 & - & 50 & - & 0.09 & 0.12 & 1.37 & 0.019 & 0.002 & - & - \\
\hline 13 & STK400 & $\mathrm{A}(\mathrm{UO})$ & B社 & $508.0 \times 26.2$ & T方向, 5 号 & 429 & 519 & - & 50 & - & 0.08 & 0.23 & 1.56 & 0.008 & 0.001 & - & - \\
\hline 14 & STK400(SS400) & $\mathrm{A}($ Bend $)+\mathrm{SR}$ & C社(D社) & $457.2 \times 30.0$ & (C方向, 1号) & (302) & (454) & - & (33) & - & 0.15 & 0.23 & 1.12 & 0.015 & 0.005 & - & - \\
\hline 15 & STK400 & $\mathrm{A}(\mathrm{UO})$ & B社 & $609.6 \times 30.0$ & T方向, 5号 & 379 & 459 & - & 56 & - & 0.08 & 0.12 & 1.37 & 0.013 & 0.002 & - & - \\
\hline 16 & STK400(SS400) & $\mathrm{A}$ (Bend) $+\mathrm{SR}$ & C社(B社) & $457.2 \times 35.0$ & (C方向, 1 号) & (299) & (463) & - & (34) & - & 0.16 & 0.18 & 0.94 & 0.017 & 0.003 & - & - \\
\hline 17 & STK400(SS400) & $\mathrm{A}($ Bend) $+\mathrm{SR}$ & C社(D社) & $457.2 \times 40.0$ & (C方向, 1号) & (322) & (461) & - & (34) & - & 0.15 & 0.22 & 1.11 & 0.013 & 0.005 & - & - \\
\hline 18 & STK400(SS400) & $\mathrm{A}$ (Bend) $+\mathrm{SR}$ & C社(D社) & $457.2 \times 45.0$ & (C方向, 1 号) & (307) & (457) & - & (36) & - & 0.15 & 0.20 & 1.11 & 0.017 & 0.005 & - & - \\
\hline
\end{tabular}

${ }^{* 1}$ STK400(SS400)は鋼管STK400の原板がSS400で, 鋼管と原板の製造メーカーが異なることを指す。

${ }^{* 2}$ E-Gは電気抵抗溶接まま, A(UO)とA(Bend)はそれぞれUO成形, 板巻成形の後に継目をサブマージアーク溶接した自動アーク溶接銅管。SRは製管後にSR処理(応力除去燒なまし処理)したもの。

${ }^{* 3} \mathrm{C}$ 社(D社) は鎆管の製造メーカーダC社，原板の製造メーカーがD社。

${ }^{*} \mathrm{~L}$ 方向は管軸方向, T方向は管周方向, 括弧内のC方向は原板(熱間圧延鋼板)の圧延直交方向, $12 \mathrm{C}$ 号等はJIS引張試験片の型式番号。伸び計測の標点距離は, $12 \mathrm{~B}, 12 \mathrm{C}, 5$ 号試験片が50mm, 1 号試 験片が $200 \mathrm{~mm}_{0}$

*5 (302)等の括弧内の数值は鋼管ではなくその)原板(熱間圧延鋼板)から採取した引張試験片をSR処理(応力除去焼なまし処理)して引張試験を行ったデータ。 
後, $0.5 \mathrm{~m}$ ずつ二つに切断し, 片方はそのまま調查し, もう片方は 焼ならし熱処理を施してから調査した。本論文では, 前者を製品ま ま(as-delivered), あるいは冷間成形まま(cold-formed)の鋼管, 後者 を焼ならし(normalized), あるいは熱処理 (heat-treated)の鋼管と 呼ぶことにし, 18 体 $\times 2$ 種の鋼管を調査する。この熱処理は鉄一炭 素平衡状態における $\mathrm{A}_{3}$ 変態点あたりの温度 (今回はす心゙て $820^{\circ} \mathrm{C} に$ 統一）まで加熱し空冷する焼ならしで, 鋼管の材質を初期化して成 形前の原板(熱間圧延鋼材)の材質を知るのが目的である。

JIS では STK 及び STKN の製造方法が製管方法と仕上げ方法の 組合せで規定されている。製管方法は電気抵抗溶接(ERW, 記号 E), 自動アーク溶接(記号 $\mathrm{A}$ ), 継目無し(記号 $\mathrm{S}$ ), 鍛接(記号 B)の 4 種類 である。このうち, 継目無鋼管は寸法精度が劣ること, 鍛接鋼管は 継目シームの強度が低いという理由で建築鉄骨ではほとんど用いら れず, もつぱら電気抵抗溶接鋼管(略称, 電縫鋼管) と自動アーク溶 接鋼管が用いられる。両者をあわせて溶接鋼管と呼んでいる。後者 の自動アーク溶接鋼管は平板から円形への成形方法により, UO 鋼 管(または UOE 鋼管) と板巻鋼管(ベンディング鋼管)の 2 種類があり, いずれも継目は直線（ストレートシーム）で，その溶接はサブマー ジアーク溶接(SAW)が主流である。今回入手した UO 鋼管, 板巻鋼 管も SAWである。

次に, 仕上げ方法は JIS で熱間仕上げ(記号 H), 冷間仕上げ(記号
C), 電気抵抗溶接まま(記号 G)の 3 種類がある。仕上げとは, 所定 の寸法に製管材を仕上げることを言い，材質を改善することが目的 ではない。したがって，現在，建築に供されている鋼管は冷間成形 鋼管であり，角形鋼管の角部ほどではないにしても，冷間加工によ って元の熱間圧延鋼材が硬化及び脆化していることを認識しておく 必要がある。硬化は降伏点と降伏比の上昇, 伸び能力の低下を招き, 塑性設計には不都合となる。脆化は破壊勒性の低下を招き, 微小な き裂が脆性破壊の引き金になりやすくなるので，構造安全上注意す べき点である。なお，今回入手した板巻鋼管 STK400-A(Bend)+SR は 4 体とも, 仕上げとは別に, 製管後に $620^{\circ} \mathrm{C}$ で応力除去焼なまし 処理(SR 処理)が施されたものであった。

試験項目は，製品ままと焼ならし熱処理したものそれぞれについ て, 材料引張試験, シャルピー衝撃試験, 残留応力測定, 及び製品 ままでの寸法測定の 4 項目である。以下, その順に試験方法と試験 結果を説明する。

\section{3. 材料引張試験とその結果 3.1 引張試験片}

製品ままの鋼管と焼ならし熱処理した鋼管からそれぞれ管軸方向 に引張試験片(JIS 14B 号, 全厚の比例試験片)をシーム溶接から離 れた位置から切り出した。試験片のつかみ部は, 試験機のチャック
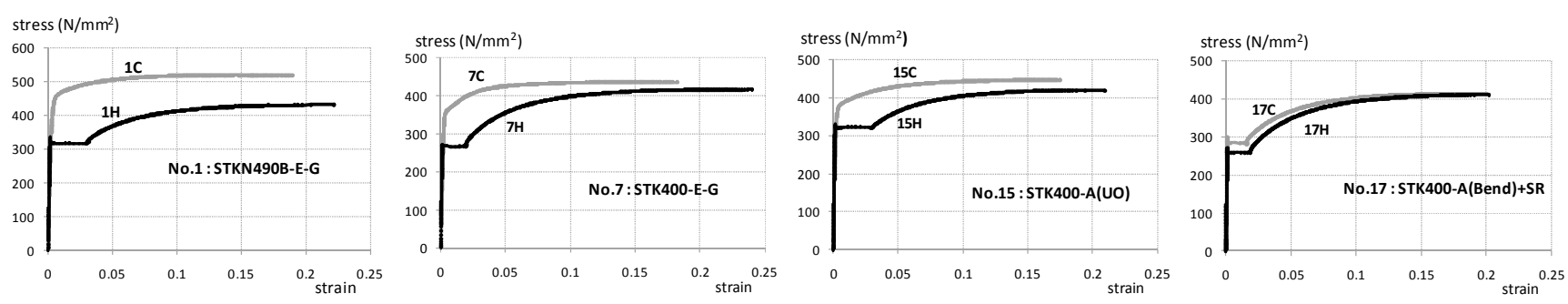

Fig.3 代表的な応カ一ひずみ曲線（管軸方向の引張試験）

Table 3 引張試験から得られた鋼管の主要な特性值

\begin{tabular}{|c|c|c|c|c|c|c|c|c|c|c|c|c|c|c|c|c|c|c|c|}
\hline \multicolumn{4}{|c|}{ 鋼管製品 ${ }^{* 1}$} & \multicolumn{8}{|c|}{ 製品ままの力学的特性值（管軸方向） ${ }^{* 2}$} & \multicolumn{8}{|c|}{ 焼ならし熱处理後の力学的特性值（管軸方向） ${ }^{* 2}$} \\
\hline $\begin{array}{l}\text { 試験体 } \\
\text { 番号 } \\
\text { No. }\end{array}$ & 規格 & 製造方法 & $\begin{array}{c}\text { 公称寸法 } \\
D_{n} \times t_{n} \\
(\mathrm{~mm})\end{array}$ & $\mid \begin{array}{l}\text { 試片 } \\
\text { 記号 }\end{array}$ & $\begin{array}{c}E \\
\left(\mathrm{~N} / \mathrm{mm}^{2}\right)\end{array}$ & $\begin{array}{c}\sigma_{y} \\
\left(\mathrm{~N} / \mathrm{mm}^{2}\right)\end{array}$ & $\begin{array}{c}\sigma_{u} \\
\left(\mathrm{~N} / \mathrm{mm}^{2}\right)\end{array}$ & $\begin{array}{l}Y R \\
(\%)\end{array}$ & $\begin{array}{l}\varepsilon_{s t} \\
(\%)\end{array}$ & $\begin{array}{l}\varepsilon_{u} \\
(\%)\end{array}$ & $\begin{array}{l}E L^{* 3} \\
(\%)\end{array}$ & $\mid \begin{array}{l}\text { 試片 } \\
\text { 記号 }\end{array}$ & $\begin{array}{c}E \\
\left(\mathrm{~N} / \mathrm{mm}^{2}\right)\end{array}$ & $\begin{array}{c}\sigma_{y} \\
\left(\mathrm{~N} / \mathrm{mm}^{2}\right)\end{array}$ & $\begin{array}{c}\sigma_{u} \\
\left(\mathrm{~N} / \mathrm{mm}^{2}\right)\end{array}$ & $\begin{array}{l}Y R \\
(\%)\end{array}$ & $\begin{array}{l}\varepsilon_{s t} \\
(\%)\end{array}$ & $\begin{array}{l}\varepsilon_{u}{ }^{{ }_{4}} \\
(\%)\end{array}$ & $\begin{array}{l}E L^{* 3} \\
(\%)\end{array}$ \\
\hline 1 & STKN490B & E-G & $457.2 \times 16.0$ & $1 \mathrm{C}$ & 195,000 & 429 & 520 & 82.5 & - & 13.2 & 32 & $1 \mathrm{H}$ & 215,000 & 316 & 432 & 73.1 & 2.9 & $>22.2$ & 39 \\
\hline 2 & STKN490B & E-G & $558.8 \times 16.0$ & $2 \mathrm{C}$ & 199,000 & 394 & 514 & 76.7 & - & 10.7 & 31 & $2 \mathrm{H}$ & 208,000 & 336 & 438 & 76.7 & 2.9 & $>23.5$ & 37 \\
\hline 3 & STK 400 & E-G & $406.4 \times 19.0$ & $3 \mathrm{C}$ & 213,000 & 428 & 494 & 86.6 & - & 6.1 & 31 & $3 \mathrm{H}$ & 209,000 & 296 & 421 & 70.3 & 2.4 & $>24.0$ & 38 \\
\hline 4 & STKN490B & E-G & $406.4 \times 19.0$ & $4 \mathrm{C}$ & 204,000 & 463 & 526 & 88.0 & - & 9.6 & 31 & $4 \mathrm{H}$ & 215,000 & 305 & 435 & 70.1 & 2.5 & $>22.2$ & 40 \\
\hline 5 & STK400 & E-G & $457.2 \times 19.0$ & $5 \mathrm{C}$ & 208,000 & 358 & 448 & 79.9 & - & 12.2 & 36 & $5 \mathrm{H}$ & 215,000 & 255 & 408 & 62.5 & 1.8 & $>24.5$ & 40 \\
\hline 6 & STK400 & E-G & $558.8 \times 19.0$ & $6 \mathrm{C}$ & 206,000 & 409 & 480 & 85.2 & - & 14.0 & 36 & $6 \mathrm{H}$ & 210,000 & 297 & 387 & 76.7 & 2.9 & $>23.5$ & 42 \\
\hline 7 & STK400 & E-G & $609.6 \times 19.0$ & $7 \mathrm{C}$ & 210,000 & 355 & 437 & 81.2 & - & 12.8 & 36 & $7 \mathrm{H}$ & 213,000 & 266 & 418 & 63.6 & 1.9 & $>27.0$ & 40 \\
\hline 8 & STK400 & $\mathrm{A}(\mathrm{UO})$ & $508.0 \times 20.6$ & $8 \mathrm{C}$ & 206,000 & 417 & 503 & 82.9 & - & 13.7 & 28 & $8 \mathrm{H}$ & 215,000 & 373 & 486 & 76.7 & 2.4 & $>22.1$ & 32 \\
\hline 9 & \begin{tabular}{|l|} 
STK K 00 \\
\end{tabular} & E-G & $508.0 \times 22.0$ & $9 \mathrm{C}$ & 204,000 & 373 & 445 & 83.8 & - & 15.2 & 31 & $9 \mathrm{H}$ & 200,000 & 268 & 434 & 61.8 & 1.3 & $>15.7$ & 29 \\
\hline 10 & STK400 & E-G & $558.8 \times 22.0$ & $10 \mathrm{C}$ & 205,000 & 365 & 430 & 84.9 & - & 15.3 & 35 & $10 \mathrm{H}$ & 207,000 & 274 & 431 & 63.6 & 2.0 & $>19.7$ & 34 \\
\hline 11 & STK400 & E-G & $609.6 \times 22.0$ & $11 \mathrm{C}$ & 200,000 & 360 & 435 & 82.8 & - & 16.1 & 34 & $11 \mathrm{H}$ & 214,000 & 275 & 423 & 65.0 & 1.9 & $>20.0$ & 38 \\
\hline 12 & STK400 & $\mathrm{A}(\mathrm{UO})$ & $609.6 \times 25.0$ & $12 \mathrm{C}$ & 207,000 & 375 & 451 & 83.1 & - & 14.8 & 34 & $12 \mathrm{H}$ & 208,000 & 323 & 427 & 75.6 & 3.1 & $>22.3$ & 39 \\
\hline 13 & STK400 & $\mathrm{A}(\mathrm{UO})$ & $508.0 \times 26.2$ & $13 \mathrm{C}$ & 206,000 & 408 & 488 & 83.6 & - & 14.7 & 34 & $13 \mathrm{H}$ & 217,000 & 373 & 470 & 79.4 & 2.1 & 18.5 & 37 \\
\hline 14 & STK400(SS400) & $\mathrm{A}$ (Bend) $+\mathrm{SR}$ & $457.2 \times 30.0$ & $14 \mathrm{C}$ & 218,000 & 325 & 451 & 72.1 & 1.4 & 15.8 & 31 & $14 \mathrm{H}$ & 215,000 & 278 & 442 & 62.9 & 1.5 & $>21.3$ & 33 \\
\hline 15 & STK400 & \begin{tabular}{|l|}
$\mathrm{A}(\mathrm{UO})$ \\
\end{tabular} & $609.6 \times 30.0$ & $15 \mathrm{C}$ & 210,000 & 372 & 446 & 83.4 & - & 15.6 & 35 & $15 \mathrm{H}$ & 213,000 & 320 & 420 & 76.2 & 3.0 & $>20.9$ & 35 \\
\hline 16 & STK400(SS400) & $\mathrm{A}$ (Bend) $+\mathrm{SR}$ & $457.2 \times 35.0$ & $16 \mathrm{C}$ & 218,000 & 313 & 442 & 70.8 & 1.3 & 14.7 & 31 & $16 \mathrm{H}$ & 218,000 & 263 & 431 & 61.0 & 1.9 & $>19.4$ & 35 \\
\hline 17 & STK400(SS400) & $\mathrm{A}$ (Bend) $+\mathrm{SR}$ & $457.2 \times 40.0$ & $17 \mathrm{C}$ & 218,000 & 283 & 414 & 68.4 & 1.6 & 18.8 & 36 & $17 \mathrm{H}$ & 215,000 & 258 & 412 & 62.6 & 1.9 & $>20.2$ & 36 \\
\hline 18 & STK400(SS400) & $\mathrm{A}$ (Bend) $+\mathrm{SR}$ & $457.2 \times 45.0$ & $18 \mathrm{C}$ & 214,000 & 283 & 404 & 70.0 & 1.7 & 18.7 & 36 & $18 \mathrm{H}$ & 216,000 & 260 & \begin{tabular}{|l|}
415 \\
\end{tabular} & 62.7 & 1.8 & $>17.9$ & 38 \\
\hline \multicolumn{20}{|c|}{ 补規格と製造方法の記号はTable 2参照。 } \\
\hline
\end{tabular}


が滑らないように平坦に切削加工した。製品ままの鋼管から切り出 した試験片は, 残留応力の解放によって曲がった状態となるが, 矯 正は行わず，そのまま試験機のチャックに固定して試験を行った。 そのため, 載荷の初期段階で試験片平行部に曲げが入ることになる が, 表と裏に貼付したひずみゲージの值の平均を用いるので, 曲げ 成分は除去される。

\section{2 材料引張試験の結果と考察}

引張試験から得られた応力一ひずみ曲線を 4 グループの代表 1 体 について Fig. 3 に掲載する。同一グループ内では応力一ひずみ曲線 が同じ形態をとるので他は省略する。一つのグラフには製品ままと 熱処理の両方が描かれており, それぞれ $1 \mathrm{C}, 1 \mathrm{H}$ のように記号を付 けてある。製品ままのものは降伏棚のない丸屋根型の曲線となるが, 製管後に SR 処理が施されていた板巻鋼管は製品ままでも降伏棚が 現れている。熱処理したものはす心゙て明瞭な降伏点及び降伏棚が現 れ, 製品ままのものよりカーブが下方にシフトする。主要な力学的 特性值を Table 3 にまとめておいた。表中のひずみ硬化開始ひずみ $\varepsilon_{s t}$ に数值が入っているものは, 降伏棚があることを意味し, その降 伏強さは下降伏点である。降伏棚のないものの降伏強さは $0.2 \%$ オ セット耐力である。冷間成形によって, 降伏強さ, 引張強さ, 降伏 比が増大寸ること, 及び一様伸びが低下することが知られているが， 今回の試験でも原板の材質に初期化した熱処理材と製品ままを比較 すればその通りになっていることが分かる。

今回実施した焼ならし熱処理によって冷間成形鋼管が成形前の原 板(熱間圧延鋼材)の性質に初期化される。そこで，冷間成形の影響 が顕著に現れる降伏強さについて製品ままと熱処理鋼管の比を径厚 比に対してプロットしたのが Fig.4 である。電縫鋼管(E-G)では STK400, STKN490B ともに径厚比が小さいほど降伏強さの上昇率 が大きくなる傾向が見られ，これは径厚比が小さいほど塑性加工の 度合いが大きくなることを示唆している。UO 鋼管と SR 処理され た板巻鋼管では径厚比の影響が見られず, 電縫鋼管より降伏強さの 上昇率が抑えられている。

焼ならし熱処理を施すと強度が鋼管の規格を満たさなくなること がある。例えば, 試験体 No.1 の引張試験片 $1 \mathrm{H}$ の降伏強さと引張 強さはそれぞれ $325,490 \mathrm{~N} / \mathrm{mm}^{2}$ に満たない。 $2 \mathrm{H}, 4 \mathrm{H}, 6 \mathrm{H}$ も同様で これらはすべて電縫鋼管である。このこと自体は製品上の瑕疪では なく, 冷間成形後の強度を保証しつつ成形性を確保するために原板 （電縫鋼管では熱延コイル）の強度を低めに設定してあるからである。 鋼管の材質を改善するために安易に熱処理すると強度不足に陥る可 能性があることを設計者は認識しておく必要がある。

ラボテストの結果(Table 3 の製品ままの力学的特性)をミルシー 卜值(Table 2) と単純に比較することはできない。両者には載荷速度, ひずみの計測方法, 試験片の標点距離, 試験片の採取方向の違いが あるからである。載荷速度は JIS でその範囲が定められているが, ミル試験では生産効率を上げるためその上限近くに設定し，ラボ試 験ではデータのサンプリング間隔を密にするため下限近くに設定す るので, 載荷速度の遅いラボ試験のほうが降伏強さ, 引張強さが低 くなる。また，ラボ試験ではひずみゲージによってひずみを計測す るが，ミル試験では伸び計でひずみを計測する。冷間成形鋼管から 採取した試験片のように曲がっている試験片に装着した伸び計では

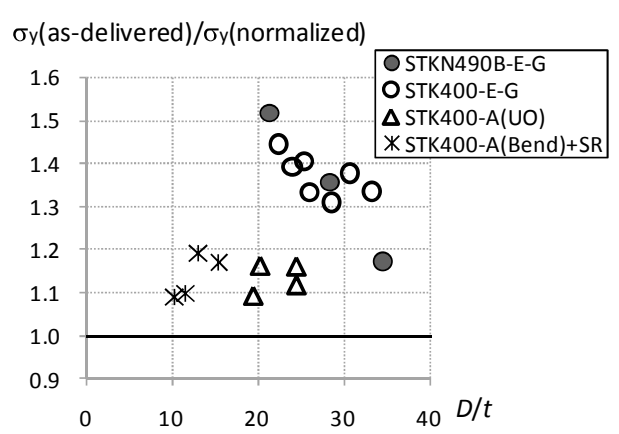

Fig.4＼cjkstart製品ままと熱処理後の降伏強さの比

弾性係数が精確に測定できないため $0.2 \%$ オフセット耐力の評価に かなり大きな誤差が生じることがある。また，ラボ試験では平行部 の長い JIS 試験片を採用して一様な応力場を得ようとするので, こ れに伴って標点距離も長くなり，その結果，破断伸びELが小さくな る。これらの違いを考慮すれば今回のミル試験值とラボ試験值に不 整合はないと考えてよい。一つ注意すべき点として，電縫鋼管の管 周方向の降伏強さ(ミル試験値)は管軸方向の降伏強さ(ラボ試験值) より小さい傾向が見られることである。製品の歩留まり上，管軸方 向よりも管周方向から引張試験片を採るほうが有利ではあるが，構 造設計では管軸方向の力学的特性のほうが重要となる。STKNでは 管軸方向の引張試験を要求しているが, STKでは方向を指定してい ないので注意を要する。

\section{4. シャルピー衝撃試験とその結果 \\ 4.1 シャルピー衝撃試験片}

シャルピー吸収エネルギーは脆性破壊に対する抵抗能力の指標と して有用であることが知られており, 試験方法の簡便さもあって, 建築構造用圧延鋼材(SN) にならって建築構造用炭素鋼鋼管(STKN)

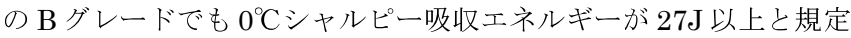
されている。ただし，一般構造用炭素鋼鋼管(STK)にはシャルピー 規定がない。

過去に行われた円形鋼管柱と $\mathrm{H}$ 形梁フランジの接合部の実験に よると，脆性破壊（厚さの小さいものでは延性破壊）が少なからず 報告されており，その様相は Fig.5 のモード C とモードLに大別さ れる。モード $\mathbf{C}$ は管周方向にき裂が進展する形式で, ダイアフラム と鋼管の溶接止端を起点とする場合 5) だけでなく, ダイアフラムが 無い場合でも梁フランジと鋼管の溶接止端を起点とするものが報告

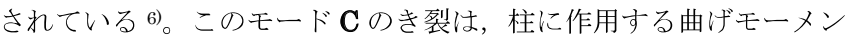
トによる管軸方向の引張応力が主因であり，梁フランジから加わる 直交方向の引張応力も多軸応力として関与寸ると考えられる。これ に対して，モードLは管軸方向にき裂が進展する形式で，ダイアフ ラムが無い場合に梁フランジの側縁と鋼管の溶接止端を起点と寸る ものがかなり報告されているが 7), 8), 9)，ダイアフラムが有る場合に もダイアフラムと梁フランジ側縁の溶接止端から発したき裂がダイ アフラムを通って柱に至ることもある 10)。このモードLのき裂は， 梁フランジ側縁に集中寸る管周方向の引張応力が主因である。 


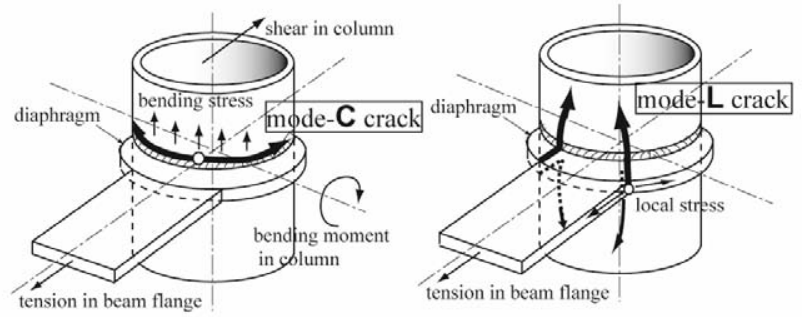

(1) ダイアフラム付き円形鋼管柱のモードC及びモードL破壊

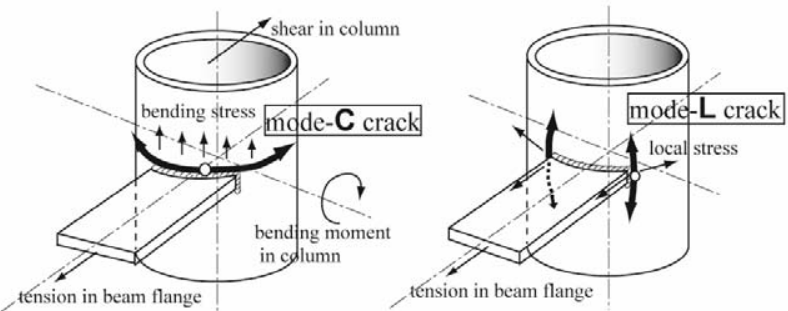

(2) ダイアフラムの無い円形鋼管柱のモードC及びモードL破壊

Fig.5 円形鋼管柱 - H 形梁フランジ接合部の破壊形式

そこで，シャルピー衝撃試験片を Fig.6 のように，管軸方向(L) 及び管周方向 $(\mathrm{C})$ のそれぞれ外面側 $(\mathrm{O})$ と内面側(I)から 3 個ずつ採取 した。試験片の V ノッチに作用する引張応力の方向から考えて, 管

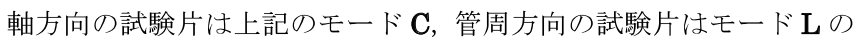
破壊に対応することになる。また，Vノッチは鋼管の外面に向け， き裂が厚さ方向に外面から内面に向かって進行する実態に合わせた。

\section{2 シャルピー衝撃試験の結果と考察}

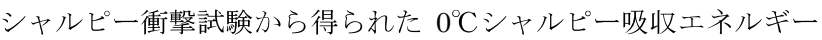
を, 管軸方向の外面 $(\mathrm{LO})$ と内面 (LI), 管周方向の外面 $(\mathrm{CO})$ と内面 $(\mathrm{CI})$ の 4 つに分けて, Fig.7 に全データをプロットした。横軸は試験体 番号 1 ～18 で, 製品ままを白抜き, 熱処理を塗りつぶしマークでプ ロットしてある。冷間加工によってシャルピー衝撃特性が低下する ことが知られているが, 今回調査した鋼管は全般的に衝撃特性が優 れており，27J を下回るものは全試料 432 個のうち 5 個のみで， 3 個の平均值が $27 \mathrm{~J}$ を回ったのは製品まま試験体 No. 17 の管周方向

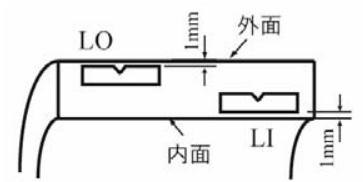

(1) 管軸方向シャルピー衝撃試験片

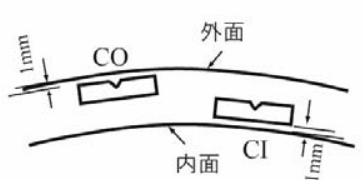

(2) 管周方向シャルピー衙撃試験片

Fig.6 シャルピー衝撃試験片の採取方向と厚さ内の位置

外面と製品まま試験体 No.18 の管周方向内面のみであった。ただし， 27J が脆性破壊を防止するために十分とは言えないので，吸収エネ ルギーが低レベルのものが存在する実態を念頭に置いておく必要が あろう。

Fig.7 を相互に見比べると, 管周方向のシャルピー吸収エネルギ 一が外面側と内面側ともに管軸方向より小さい傾向が見て取れる。 そこで，管軸方向に対する管周方向の比（3 個の平均值の比）をプ ロットしてみると Fig.8のようであり，やはり，ほとんどの鋼管に おいて管周方向のほうが管軸方向より破壊勒性が低い。STKN の JIS 規格ではシャルピー衝撃試験片を管軸方向から採取することが 規定されているが，管周方向はその值より小さい傾向があることに 注意する必要がある。このことは前出 Fig. 5 のモード L の破壊が侮 れないことを示唆している。

熱処理によってシャルピー吸収エネルギーがどの程度向上するか, 逆に言えば，冷間成形によって原板の勒性がどの程度失われたかを 見るために，製品ままのシャルピー吸収エネルギーに対する熱処理 材の比をとったものを Fig.9に示す。1.0を超えるもの，すなわち熱 処理によって勒性が回復するものが多いが，No.18のように一部逆 になっているものも見られる。これは熱処理過程での結晶粒成長に 関わる微量元素の有無に依るものと考えられる。UO 鋼管（試験体 No.8, 12, 13, 15) は管軸方向，管周方向とも同程度に高いシャルピ 一衝撃特性を示しており，熱処理に依ってもほとんど変化していな
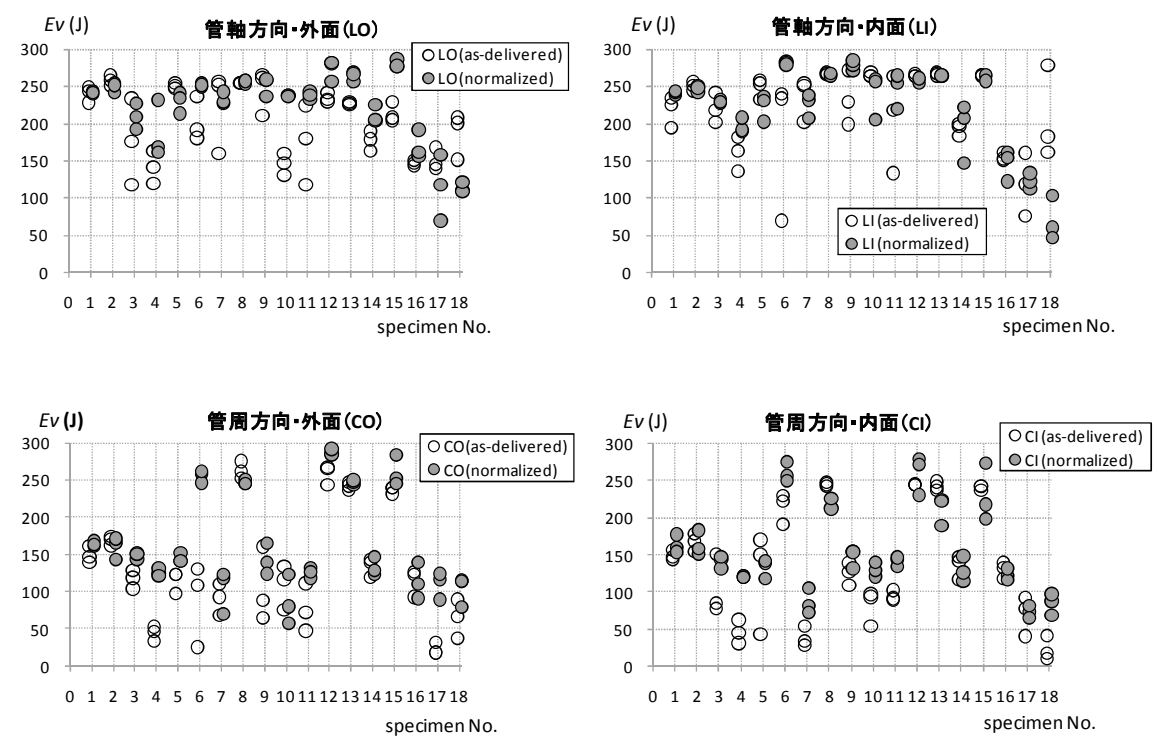

Fig.7 $\quad 0^{\circ}$ Cシャルピー吸収エネルギー

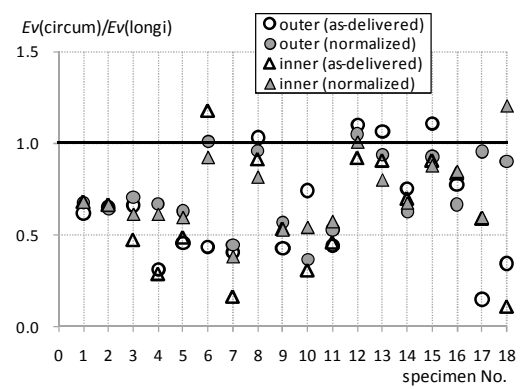

Fig.8 管軸方向に対する管周方向のシャ ルピー吸収エネルギーの比

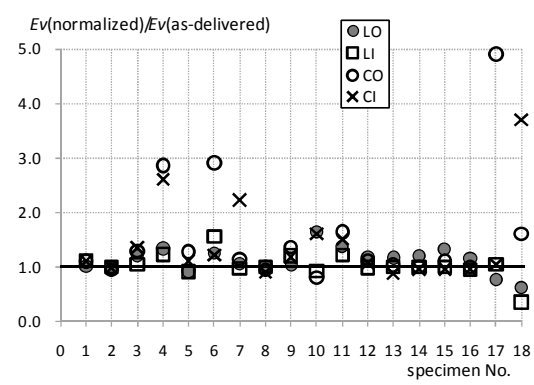

Fig.9 熱処理によるシャルピー吸収エ ネルギーの増加率 
い。その化学成分を Table 2 で見ると, 炭素含有量が少なく, 勒性 を高める働きをするマンガンが多く含まれている。

\section{5. 残留応力測定とその結果}

\section{1 残留応力の測定方法}

一般に，残留応力の測定は切断法による。よく行われるのは，ひ ずみゲージを貼付した後, その周辺を切断して解放されたひずみを 測定し，それを残留ひずみとするものである。残留応力は直接測定 することはできないが，残留ひずみに弾性係数を乗じて計算する。 ただし，実際の残留応力は多軸状態にあるので解放ひずみから残留 応力を正確に求めるのは難しく, 厚さの内部の解放ひずみをひずみ ゲージで測ることができない点に限界がある。このひずみゲージ法 はゲージを貼付した箇所の局所的な解放ひずみが得られるわけであ って, 非一様に分布している残留応力の大域的な様相を知るには多 数のひずみゲージを密に貼付する必要がある。薄肉小径の電縫鋼管 の残留応力をひずみゲージで調べた既往研究 2),3，4)によると, 残留 応力は Fig.10のような分布をしており, 管周方向と管軸方向とも外 面が引張, 内面が圧縮の残留応力状態となっている。すなわち, 切 断による解放ひずみは外面が圧縮, 内面が引張となる。

もう一つの方法は，切断後に生じる変形を測定する方法で，大域 的あるいは平均的な残留ひず夕を知ることができる。本研究では大 型の鋼管を対象としているので，ひずみゲージを貼付したままその
周辺を切断するのは困難と考え，この変形測定方法を用いることに した。残留応力を変形測定によって調べる方法はあまり知られてい ないので，その手順と計算根拠について以下に説明する。残留ひず みと残留応力は可逆的な弾性力学量であるので，これらは弾性力学 によって定量化できる。

\section{2 管周方向残留応力の測定方法}

管周方向については，Fig.11のように，鋼管を輪切りにしてリン グを取り出す。リングの幅を小さくとれば（今回 $20 \mathrm{~mm}$ )，管軸方 向の残留応力は解放されるので, 切断後は管周方向の一軸応力状態 を考えればよい。ただし，ポアソン比により管周方向の残留ひずみ も部分的に解放されるので管周方向残留応力が低めに評価されるこ とに注意する必要がある。次に, リングの 1 か所を切断すると（今 回はシーム溶接部で切断), 管周方向の残留ひずみが解放されて輪が 拡がる。ただし, 残留応力の分布が Fig.10 と逆になっていると輪が 縮まるが，いずれの場合も数理的には正負の符号が逆になるだけで 同じように扱うことができる。

切断前のリングの厚さの中心を通る円の半径を $r_{o}$ とする。切断後 の隙間を含んだ外周長を巻尺で測定しそれを $l_{1}$ とすれば，厚さ $t$ 中 心を通る円の半径 $r_{1}=l_{1} / 2 \pi-t / 2$ が定まる。曲率の変化 $\Delta \phi=1 / r_{o}-1 / r_{1}$ がリング断面の曲げ岡性 $E I$ を介して解放曲げモー メント $M_{r C}=E I \Delta \phi$ と対応付けられ，この解放曲げモーメントに対応 して最外縁の管周方向残留応力 $\sigma_{r C}=M_{r C} t / 2 I$ が次式で求められる。

$$
\sigma_{r C}=\frac{E t}{2}\left(\frac{1}{r_{o}}-\frac{1}{r_{1}}\right)
$$

式中の $E$ はヤング係数で, $E=205,000 \mathrm{~N} / \mathrm{mm}^{2}$ とする。厳密には, この問題に曲がり梁の理論を適用する必要があるが，本研究で対象 とした径厚比が 10 以上の鋼管では，曲げの中立軸を厚さの中心と する上記の簡便法を使っても誤差は $8 \%$ 以下である。

1 か所で切断したリングをさらに反対側で切断すると，半円弧が 2 個できる。図のように両端の厚さ中心点間距離 $l_{2}$ と厚さ中心線の

Fig.10 電縫鋼管の残留応力分布

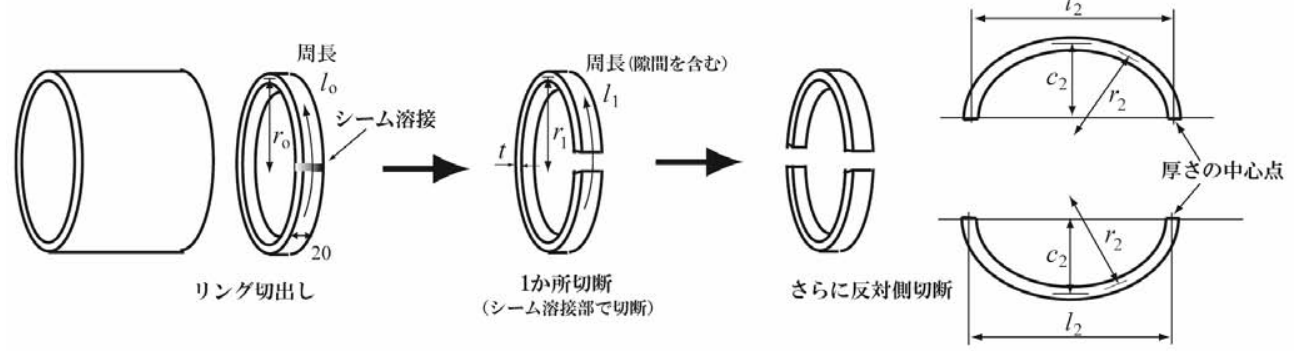

Fig.11 管周方向の残留応力を調べるための切断法

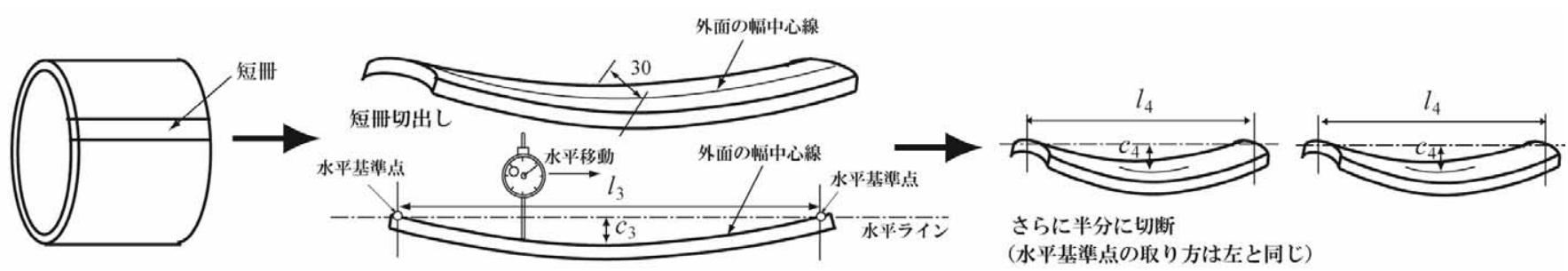

Fig.12 管軸方向の残留応力を調べるための切断法 
むくり $c_{2}$ を大型ノギスで測定すれば，厚さの中心を通る円弧の半径 $r_{2}$ は，幾何学的な関係から次式で表される。

$$
r_{2}=\frac{\frac{l_{2}{ }^{2}+c_{2}{ }^{2}}{2 c_{2}}}{2}
$$

この $r_{2}$ を(1)式の $r_{1}$ と置き換えれば, 半リングの残留応力が求めら れる。初めの 1 か所切断で残留応力が完全に解放され, かつ管周に 沿って残留応力が一様であれば， $r_{1}=r_{2}$ となるが，実際にはそうな っていないので多少の違いが生じる。

上式の $\sigma_{r c}$ が正のときは切断することによって円弧が拡がる場合 であり, 管周方向の残留応力は外面が引張, 内面が圧縮であったこ とを意味する。平板を単純に冷間曲げのみによって円筒に成形する と必ずそのようになるが, 後で見るように, それ以外の成形力が作 用寸ると残留応力のパターンが異なってくる。また, 熱処理した鋼 管では $\sigma_{r c}$ が負になることがある。その理由は, 加熱によって残留応 力が除去されるとともに, 鋼管の外面が先に冷却硬化し, 遅れて冷 却収縮する内面が外面側の拘束を受けて引っ張られ, その反作用と して外面が圧縮されるためである。

\section{3 管軸方向残留応力の測定方法}

次に，管軸方向については，Fig.12のように，管軸に平行な帯状 の短冊（今回は幅 $30 \mathrm{~mm} \times$ 長さ $465 \mathrm{~mm}$ ）を鋼管から切り出す。す ると, 管軸方向の残留ひずみが解放されて短冊は内面側が凸となる ように曲がる(電縫鋼管の場合)。熱処理鋼管では逆方向に曲がるこ とがあるが，その理由は上で述べたのと同様である。

短冊の両端を水平定盤上で支持し, 水平基準点間の長さ $l_{3}$ とむく り $c_{3}$ を測定する。むくりは，ダイヤルゲージを短冊の外面の幅中心 線に沿って水平にスライドさせながら測定し，その最大值をとる。 残留ひずみの解放によって生じる円弧の半径, 寸なわち曲率半径 $\rho$ は(2)式と同様の考えで,

$$
\rho=\frac{\frac{l_{3}^{2}}{4}+c_{3}^{2}}{2 c_{3}}
$$

となる。よって, 管軸方向の解放曲げモーメント $M_{r L}=E I / \rho$ から, 最外縁の曲げ応力度は次式で与えられる。

$$
\sigma_{r L}=\frac{M_{r L}}{2 I / t}=\frac{E t}{2 \rho}
$$

図のように，短冊を長さ方向にさらに 2 分割して同様の測定を行 い，長さ $l_{4}$ とむくり $c_{4}$ から片側それぞれの残留応力を求めることが

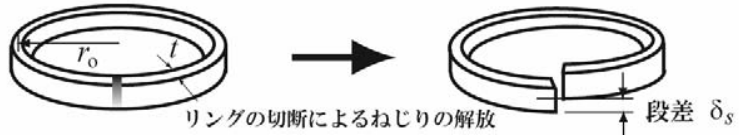

Fig.13 残留せん断応力を調べるための切断法

できる。

鋼管から切り離された管軸方向の短冊が内面側を凸とするように 曲がるとき，管軸方向の残留応力は外面側が引張，内面側が圧縮で あったことを意味寸る。鋼板を円形に冷間で曲げ成形したとき，管 周方向だけでなく管軸方向にも残留曲げモーメントが入る理由は, 平面ひずみ状態で管周方向に曲げひずみを与えると同じ符号の曲げ 応力度が直交方向すなわち管軸方向に生じるからである。

\section{4 残留せん断応力の測定方法}

鋼管から切り出したリングの一か所を切断すると, 前述のように 輪が拡がる（あるいは縮まる）が, それと同時に, Fig.13のように, 輪がねじれて切り口に段差ができることがある。これは内部に封じ 込められていたねじりモーメントが解放されることによって生じる ものである。この残留ねじりは鋼管の製造過程で，合せ目がずれた 状態（成形ロールの駆動力の不均衡によりねじりモーメントが入っ た状態）でシーム溶接されることによる。これに伴い，断面内部に はせん断応力が残留応力として封印され，リングの一か所を切断す ると，そのせん断ひずみが解放されて段差が生じる。円形鋼管の場 合は管軸直交方向に切断しても軸対称断面であるので，スリットを 入れない限りねじり変形が顕在化しないが，この円形鋼管をさらに 成形した角形鋼管を切断すると残留㸚じりが解放されて断面にゆが みが生じることがある。

断面内の残留せん断応力は, シーム溶接する直前の開断面の状態 で導入されるので，鋼管断面の厚さ中心でゼロ，外面と内面で向き が逆で大きさは最大となる。この内外面の残留せん断応力 $\tau_{r}$ は, リ ング切断面の切り口に生じる段差を $\delta_{s}$ とすると, ねじりの膜類似理 論を援用して反り関数を導くことにより ${ }^{11)}$ ，次式で与えられる。こ こで，せん断弾性係数を $G=79,000 \mathrm{~N} / \mathrm{mm}^{2}$ とする。

$$
\tau_{r}=\frac{G t}{2 \pi r_{o}^{2}} \delta_{s}
$$

\section{5 残留応力の測定結果と考察}

製品ままの鋼管の外面の管軸方向残留応力 $\sigma_{r L}$ と管周方向残留応 力 $\sigma_{r c}$ (いずれも引張応力を正), 及び残留せん断応力 $\tau_{r}$ を径厚比に

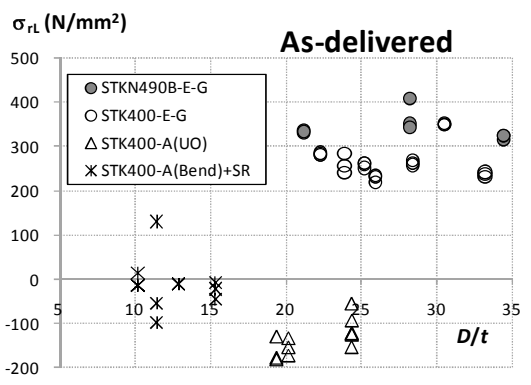

Fig.14 管軸方向外面の残留応力

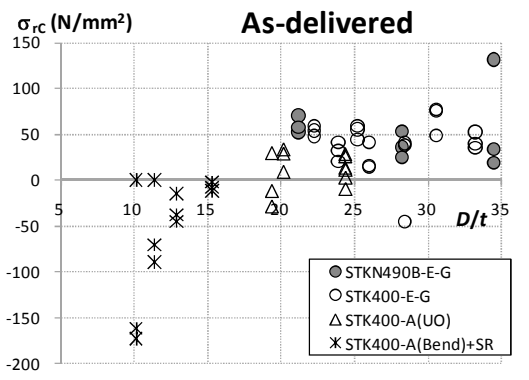

Fig.15 管周方向外面の残留応力

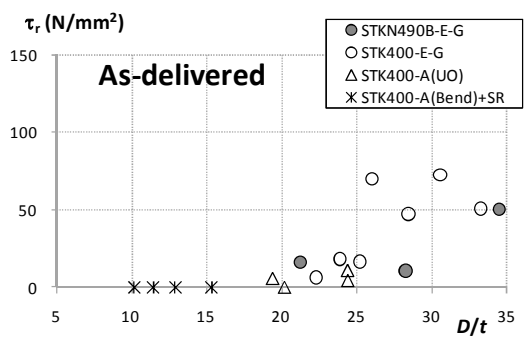

Fig.16 残留せん断応力 
対してプロットしたものを Fig.14, Fig15, Fig16 に示す。前 2 者 は各鋼管につき切断片 3 個のデータをプロットしてある。この $3 つ$ のグラフを総覧して気づく大きな特徴は, 電縫鋼管, UO 鋼管, 板 巻鋼管の残留応力が全く異なった様相を呈していること, 及び電縫 鋼管の管軸方向残留応力が際立って大きいことの 2 点である。管軸 方向の残留応力のほうが管周方向より大きいことは, 薄肉小径の電 縫鋼管の残留応力をひずみゲージ法で調べた既往研究 3), 4)の知見と 一致している。以下, 少し詳しく観察してみる。

管軸方向の残留応力（Fig.14）は, 電縫鋼管では $300 \mathrm{~N} / \mathrm{mm}^{2}$ 前後 に達しており，これは Table 3 に掲載した焼ならし熱処理によって 初期化した鋼管すなわち成形前の原板の降伏強さのレベルに達して おり, 引張強さ近くまで達しているものもある。これは塑性加工に よる必然の結果であるが, 鋼管の外面で管軸方向に大きな引張残留 応力が入っていることに対しては構造安全上の注意が必要であろう。 つまり, 弾性限耐力にはほとんど余裕が無いことになるので，延性 と勒性によって安全性を確保するというスタンスが不可欠である。 電縫鋼管とは違って, UO 鋼管では残留応力の正負が逆転しており, 外面が圧縮で, 残留応力の大きさは $150 \mathrm{~N} / \mathrm{mm}^{2}$ 前後である。これは $\mathrm{U}$ 型曲げ成形, $\mathrm{O}$ 型プレス成形に続く拡管成形(Expand)の影響を受 けているものと考えられる。板巻鋼管は SR 処理が施されていたた め, 残留応力は比較的小さく, 外面がほとんどにおいて圧縮である。 $\mathrm{SR}$ 処理によって外面が圧縮になるのは, 加熱後の徐冷過程で外面 側の泠却が先行するためと考えられる。

管周方向の残留応力（Fig.15）は，管軸方向に比べて小さい。電 縫鋼管でさえ, $50 \mathrm{~N} / \mathrm{mm}^{2}$ 前後に収まっており, UO 鋼管ではそれよ り小さく, SR 処理された板巻鋼管ではほとんどゼロか, 外面側が 圧縮である。ただし, 前述のようにリング切出し時に管周方向残留 ひずみが部分的に解放されるので, 実際の管周方向残留応力はこれ より高めになっていると考えられる。

残留せん断応力（Fig.16）は, 電縫鋼管にのみ観察され（最大で $70 \mathrm{~N} / \mathrm{mm}^{2}$ 程度), UO 鋼管と板巻鋼管ではほとんどゼロである。電 縫鋼管では径厚比の大きいほど残留せん断応力が高くなる傾向が見 られる。これは圧延ロールの駆動力によって厚さの小さいものほど
ねじりが入りやすいためであろうと推測される。シーム溶接される 直前の円状開断面の㸚じり定数は $2 \pi r_{o} t^{3} / 3$ で, 厚さの 3 乗に比例す るからである。上記の $70 \mathrm{~N} / \mathrm{mm}^{2}$ は原板の降伏せん断応力度の約 $40 \%$ で，管軸方向残留応力と比べればさほど大きな值ではない。残 留せん断応力を計算する際に用いるリング切断面の段差は電縫鋼管 で最大 $23 \mathrm{~mm}$ （試験体 No.6）であったが，この段差はシーム溶接 直前の合せ目の材軸方向のずれ，すなわちねじり理論における反り である。つまり，23mm の反りを生じさせるねじりモーメントが加 えられた状態でシーム溶接されたと推定される。電縫鋼管とは成形 方法の異なるUO 鋼管と板巻鋼管ではこのようなねじりがほとんど 入らないと考えられる。

焼ならし熱処理した鋼管の残留応力は製品ままのものよりはるか に小さかったので詳細は割愛するが，管軸方向残留応力は，外面の 冷却が先行寸るために，外面が圧縮となる傾向が見られ，その大き さは $50 \mathrm{~N} / \mathrm{mm}^{2}$ 程度以下であった。管周方向の残留応力と残留せん 断応力はいずれもゼロとみなしうる結果であった。

\section{6. 鋼管の寸法測定とその結果 \\ 6.1 鋼管の寸法許容差}

鋼管の寸法は外径, 厚さ, 長さで表され, 公称值（指定值，規定 值ともいう) と実測值がある。ここでは公称值(nominal)に対して添 え字 $n$ を付け, 公称外径, 公称厚さ, 公称長さをそれぞれ $D_{n}, t_{n}, L_{n}$ で 表す。実測值には一個で代表する測定值のほかに複数の測定值から 得られる最大值, 最小值, 平均值がある。ここでは一個の代表測定 值は添え字なしとし, 後の三者はそれぞれに添え字 $\max , \min$, aveを 付ける。

実際の製品寸法には誤差があり，誤差が大きいと鉄骨などの二次 製品の製作に支障をきたすので，許容誤差（公差）が鋼材規格で定 められている。本論では薄肉小径の鋼管は除外し，柱材として想定 される $D \geq 100 \mathrm{~mm}, t \geq 12 \mathrm{~mm}, D / t \leq 100$ の鋼管の許容誤差につい $\tau \mathrm{JIS}^{12)}$ ，欧州 $\left.\left.\mathrm{EN}^{13}\right), 14\right) ，$ 米国 $\mathrm{ASTM}^{15}$ の最新規定 (2014 年時点) を比較したものを Table 4 に示寸（ただし，継目無鋼管を除く）。鋼 管の寸法精度に関する JIS 規格は国際的にみて甘く, EN 規格がも

Table 4 鋼管の寸法許容差の国際比較

（継目無鋼管を除 $<，$ 外径 $D \geqq 100 \mathrm{~mm}$, 厚さ $t \geqq 12 \mathrm{~mm}$, 径厚比 $D / t \leqq 100)$

\begin{tabular}{|c|c|c|c|c|c|c|c|}
\hline 規格名 & 外径 $D$ & 厚さ $t$ & 真丹度 & 宾直度 & 質量 & 長さ & 溶接ビード高さ \\
\hline $\begin{array}{l}\text { JIS G } 3444^{-2010} \\
\text { 一般構造用炭素鋼鋼管 (STK) }\end{array}$ & 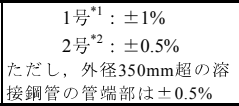 & $\begin{array}{l}1 \text { 号 }^{* 1}:-1.5 \mathrm{~mm} \sim+15 \% \\
2 \text { 号 }^{* 2}:-1.2 \mathrm{~mm} \sim+10 \%\end{array}$ & 規定なし & $\begin{array}{c}\text { 実用的に真っすぐ } \\
\text { (数值規定なし) }\end{array}$ & 規定なし & $\begin{array}{l}\text { 指定なき限り指定長さ以上, } \\
\text { または受渡当事者閏協定 }\end{array}$ & 規定なし \\
\hline $\begin{array}{l}\text { JIS G } 3475^{-2008} \\
\text { 建築構造用炭素鋼鋼管 (STKN) }\end{array}$ & $\begin{array}{l} \pm 1 \% \\
\text { ただし，外彺 } 350 \mathrm{~mm} \text { 超の溶 } \\
\text { 接鋼管の管端部は土0.5\% } \\
\end{array}$ & $-0.5 \mathrm{~mm} \sim+15 \%$ & 規定なし & $\begin{array}{l}\text { 実用的に真っすぐ } \\
\text { (数值規定なし) }\end{array}$ & 規定なし & $\begin{array}{l}\text { 指定なき限り指定長さ以上, } \\
\text { または受渡当事者問協定 }\end{array}$ & 規定なし \\
\hline $\begin{array}{l}\text { BS EN 10210-2:2006 } \\
\text { Hot finished structural hollow sections of } \\
\text { non-alloy and fine grain steels - Part } 2\end{array}$ & $\pm 1 \%$, かつ $\pm 10 \mathrm{~mm}$ & $\begin{array}{c}-10 \% \\
+ \text { +公差は質量公差による }\end{array}$ & $2 \%$ & $\begin{array}{l}\text { 全長に対して } 0.2 \% \\
\text { どの } 1 \mathrm{~m} に \text { 対しても } 3 \mathrm{~mm}\end{array}$ & \begin{tabular}{|l|} 
個々の製品長 \\
さにつき $6 \%$
\end{tabular} & $\begin{array}{l}\text { 長さ指定の時(Exact), } \\
2 \leqq L \leqq 6 \mathrm{~m}: 0 \sim+10 \mathrm{~mm} \\
L>6 \mathrm{~m}: 0 \sim+15 \mathrm{~mm}\end{array}$ & $\begin{array}{l}\text { サブマージアーク溶接 } \\
\text { (内外面とも) 最大值 } \\
t \leqq 14.2 \mathrm{~mm}: 3.5 \mathrm{~mm} \\
t>14.2 \mathrm{~mm}: 4.8 \mathrm{~mm} \\
\end{array}$ \\
\hline $\begin{array}{l}\text { BS EN 10219-2:2006 } \\
\text { Cold formed welded structural hollow } \\
\text { sections of non-alloy and fine grain steels - } \\
\text { Part } 2\end{array}$ & $\pm 1 \%$, かつ $\pm 10 \mathrm{~mm}$ & $\begin{aligned} D \leqq & \leqq 406.4 \mathrm{~mm}: \\
D & >406.4 \mathrm{~mm}: \\
& \pm 10 \%, \quad \text { から } \pm 2 \mathrm{~mm}\end{aligned}$ & $2 \%$ & $\begin{array}{l}\text { 全長に対して } 0.2 \% \\
\text { どの } 1 \mathrm{~m} に \text { 対しても } 3 \mathrm{~mm}\end{array}$ & \begin{tabular}{|l|} 
個々の製品長 \\
さにつさ $\%$ \%
\end{tabular} & $\begin{array}{l}\text { 辰さ指定の時(Exact), } \\
\mathrm{L}<6 \mathrm{~m}: 0 \sim+5 \mathrm{~mm} \\
6 \leqq L \leqq 10 \mathrm{~m}: 0 \sim+15 \mathrm{~mm} \\
L>10 \mathrm{~m}: \\
0 \sim+(5 \mathrm{~mm}+1 \mathrm{~mm} / \mathrm{m}) \\
\end{array}$ & $\begin{array}{l}\text { サブマージアーク溶接 } \\
\text { (内外面とも) 最大值 } \\
t \leqq 14 \mathrm{~mm}: 3.5 \mathrm{~mm} \\
t>14.2 \mathrm{~mm}: 4.8 \mathrm{~mm}\end{array}$ \\
\hline $\begin{array}{l}\text { ASTM A500/A500M-13 } \\
\text { Cold-formed welded and seamless carbon } \\
\text { steel structural tubing in rounds and shapes }\end{array}$ & $\pm 0.75 \%$ & $\pm 10 \%$ & 規定なし & 全長に対して $0.2 \%$ & 規定なし & $\begin{array}{l}\text { 長さ指定の時(Specific), } \\
L \leqq 6.5 \mathrm{~m}:-6 \sim+13 \mathrm{~mm} \\
L>6.5 \mathrm{~m}:-6 \sim+19 \mathrm{~mm}\end{array}$ & 規定なし \\
\hline $\begin{array}{l}\text { ASTM A501-07 } \\
\text { Hot-formed welded and seamless carbon } \\
\text { steel structural tubing }\end{array}$ & $\pm 1 \%$ & 規定なし & 規定なし & 全長に対して $0.2 \%$ & $\begin{array}{l}\text { 個々の製品長 } \\
\text { さにつき } \\
\quad-3.5 \%\end{array}$ & \begin{tabular}{|l|} 
長さ指定の時(Specific), \\
$L \leqq 6.7 \mathrm{~m}:-6.4 \sim+12.7 \mathrm{~mm}$ \\
$6.7<L \leqq 13.4 \mathrm{~m}:$ \\
$\quad-6.4 \sim+19 \mathrm{~mm}$
\end{tabular} & 規定なし \\
\hline
\end{tabular}

(注) ${ }^{* 1} 1$ 号は特に指定が無い場合。 ${ }^{* 2} 2$ 号は特に指定が有る場合。 
っとも厳しく設定されている。JIS に規定のない真円度(Out of roundness) と真直度(Straightness)は $\mathrm{EN}^{13)}$, 14) で定義されている次 式を用いることにする（記号は Fig.17 参照）。真円度と真直度は值 が 0 のとき, それぞれ完全な円, 直線を表し, 值が大きくなると真 円, 直線から外れていく。

$$
\begin{array}{r}
O_{r}=\frac{D_{\max }-D_{\min }}{D_{n}} \times 100(\%) \\
S_{t}=\frac{e}{L} \times 100(\%)
\end{array}
$$

真円度は, 鋼管柱どうしの現場突合せ継手で目違いが大きくなら ないように規定しておく必要があるが, 現行 JIS では真円度の規定 がない。告示 1464 号では厚さが $15 \mathrm{~mm}$ を超える場合の食い違いは 厚さの $1 / 10$ 以下かっ $3 \mathrm{~mm}$ 以下となっており, それを超える場合は 適切な補強を要する。真円度は, 外径の許容差とは独立のものであ ることに注意する必要がある（鋼管の外径は周長から計算で求める ことが許されているので，真円度とは無関係である)。

真直度は柱の建て方精度だけでなく圧縮耐力にも関係するので, 学会 JASS 616)では 0.1\%以下に制限してあるが, 現行 JIS の鋼管に は曲がりの規定がない。このことは角形鋼管についても同様の状況

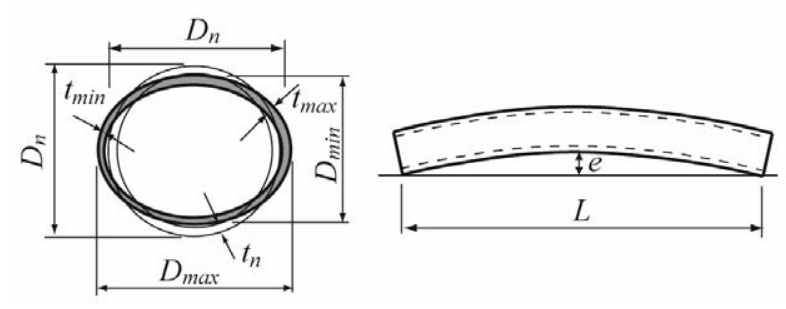

Fig.17 鋼管の寸法の定義
にあり,一般構造用角形鋼管(JIS G 3466)の真直度は $0.3 \%$ 以々と う甘い制限になっている。ただし，建築構造用冷間成形角形鋼管 $\mathrm{BCR}, \mathrm{BCP}$ では製品長さ $9 \mathrm{~m}$ 未満と以上につき，曲がり $e$ を全長の 1/1500 以下, 1/1250以下という比較的厳しい制限を与えており 17), JASS 6 と整合している。かつて鉄骨柱に多用された $\mathrm{H}$ 形鋼の真直 度は JIS G 3192 において 0.1\%以下（せいが $300 \mathrm{~mm}$ 以下では $0.15 \%$ 以下）と規定されている。

\section{2 寸法の測定方法}

今回入手した鋼管は JIS にある「管端部」が特定できなかったの で，両端を区別せずに扱うこととし，周長，外径，厚さの測定は納 品された $1 \mathrm{~m}$ 長さの両端で行った。平均外径 $D_{a v e}$ はJIS に準拠して 巻尺による外周長の測定值を $\pi=3.1416 て ゙$ 除して計算し, 両端の值 を平均した。最大外径 $D_{\max }$ と最小外径 $D_{\min }$ については, 端部断面の シーム溶接部を起点 (0 時) として時計の文字盤と同様に 12 等分し, 対角位置（例えば 1 時と 7 時）を順次ずらしながら， 6 か所の直径 を大型ノギスで測定し，その中から $D_{\text {max }}$ と $D_{\text {min }}$ を見つけて上記の真 円度を計算し, 両端の真円度の大きいほうの值を採用した。最大厚 さ $t_{\text {max }}$ と最小厚さ $t_{\text {min }}$ もほぼ同様の手順によってマイクロメータで 測定し, 平均厚さ $t_{a v e}$ は両端の全測定值の単純平均とした。曲がり $e$ は，測定区間が僅か $1 \mathrm{~m}$ しかない関係で非常に小さかったので，鋼 管の外面の長手方向に直線定規を当て最も隙間が大きいとみられる 箇所をすきまゲージで測定した。溶接ビード高さは端部断面で外面 と内面それぞれについてノギスで測定して両端の值の大きいほうを 採用した。なお, ビード切削仕上げを行っている電縫鋼管はビード 高さ0である。

\section{3 寸法の測定結果と考察}

寸法の測定結果に基づく誤差を一覧表にしたものを Table 5 に示 す。表の下段には, 18 試験体の最小值と最大值, 及び寸法精度の規 定が厳格な BS EN 10219 の許容差を記入してある。全体的に寸法

\begin{tabular}{|c|c|c|c|c|c|c|c|c|c|c|c|c|}
\hline \multirow[b]{2}{*}{$\begin{array}{l}\text { 試験体 } \\
\text { 番号 } \\
\text { No. }\end{array}$} & \multicolumn{2}{|c|}{ 公称寸法 } & \multicolumn{2}{|c|}{ 外径の誤差 } & \multicolumn{2}{|c|}{ 厚さの誤差 } & \multirow{2}{*}{$\begin{array}{c}\text { 真円度 } \\
O_{r} \\
(\%)\end{array}$} & \multirow{2}{*}{$\begin{array}{c}\text { 曲がり } \\
e \\
(\mathrm{~mm})\end{array}$} & \multirow{2}{*}{$\begin{array}{c}\text { 真直度 } \\
S_{r} \\
(\%)\end{array}$} & \multirow{2}{*}{\begin{tabular}{|c|} 
長さの誤差 \\
$\begin{array}{c}L-L_{n} \\
(\mathrm{~mm})\end{array}$ \\
\end{tabular}} & \multicolumn{2}{|c|}{ 溶接ビード高 } \\
\hline & $\begin{array}{c}D_{n} \times t_{n} \\
(\mathrm{~mm})\end{array}$ & $\begin{array}{c}L_{n} \\
(\mathrm{~mm})\end{array}$ & $\begin{array}{c}D_{\text {ave }}-D_{n} \\
(\mathrm{~mm})\end{array}$ & $\begin{array}{c}\left(D_{\text {ave }}-D_{n}\right) / D_{n} \\
\times 100 \\
(\%) \\
\end{array}$ & $\begin{array}{c}t_{\text {ave }}-t_{n} \\
(\mathrm{~mm})\end{array}$ & $\begin{array}{c}\left(t_{\text {ave }}-t_{n}\right) / t_{n} \\
\times 100 \\
(\%) \\
\end{array}$ & & & & & $\begin{array}{l}\text { 外面 } \\
(\mathrm{mm})\end{array}$ & $\begin{array}{l}\text { 内面 } \\
(\mathrm{mm})\end{array}$ \\
\hline 1 & $457.2 \times 16.0$ & 1,000 & 1.1 & 0.24 & 0.24 & 1.5 & 0.17 & 0.2 & 0.02 & 2.5 & 0.0 & 0.0 \\
\hline 2 & $558.8 \times 16.0$ & 1,000 & 1.0 & 0.18 & 0.25 & 1.6 & 0.20 & 0.2 & 0.02 & 1.5 & 0.0 & 0.0 \\
\hline 3 & $406.4 \times 19.0$ & 1,000 & 0.8 & 0.19 & -0.72 & -3.8 & 0.25 & 0.1 & 0.01 & 1.0 & 0.0 & 0.0 \\
\hline 4 & $406.4 \times 19.0$ & 1,000 & 1.8 & 0.43 & 0.26 & 1.4 & 0.10 & 0.1 & 0.01 & 1.0 & 0.0 & 0.0 \\
\hline 5 & $457.2 \times 19.0$ & 1,000 & 1.0 & 0.22 & -0.82 & -4.3 & 0.39 & 0.2 & 0.02 & 1.0 & 0.0 & 0.0 \\
\hline 6 & $558.8 \times 19.0$ & 1,000 & 1.0 & 0.17 & -0.67 & -3.5 & 0.43 & 0.3 & 0.03 & 2.5 & 0.0 & 0.0 \\
\hline 7 & $609.6 \times 19.0$ & 1,000 & 1.0 & 0.16 & -0.62 & -3.3 & 0.20 & 0.2 & 0.02 & 0.0 & 0.0 & 0.0 \\
\hline 8 & $508.0 \times 20.6$ & 1,000 & 0.6 & 0.13 & 0.24 & 1.2 & 0.63 & 0.5 & 0.05 & 0.0 & 0.0 & 1.5 \\
\hline 9 & $508.0 \times 22.0$ & 1,000 & 0.8 & 0.15 & -0.69 & -3.1 & 0.28 & 0.1 & 0.01 & 3.6 & 0.0 & 0.0 \\
\hline 10 & $558.8 \times 22.0$ & 1,000 & 0.8 & 0.14 & -0.45 & -2.0 & 0.20 & 0.2 & 0.02 & 1.8 & 0.0 & 0.0 \\
\hline 11 & $609.6 \times 22.0$ & 1,000 & 0.3 & 0.05 & -0.55 & -2.5 & 0.21 & 0.3 & 0.03 & 2.2 & 0.0 & 0.0 \\
\hline 12 & $609.6 \times 25.0$ & 1,000 & 0.7 & 0.11 & 0.02 & 0.1 & 0.31 & 0.5 & 0.05 & 1.0 & 2.5 & 1.8 \\
\hline 13 & $508.0 \times 26.2$ & 1,000 & 0.6 & 0.12 & 0.04 & 0.1 & 0.47 & 0.5 & 0.05 & 1.5 & 2.0 & 1.5 \\
\hline 14 & $457.2 \times 30.0$ & 1,000 & 0.9 & 0.19 & -0.06 & -0.2 & 0.59 & 0.3 & 0.03 & 0.2 & 0.0 & 0.8 \\
\hline 15 & $609.6 \times 30.0$ & 1,000 & 1.3 & 0.21 & 0.27 & 0.9 & 0.16 & 0.2 & 0.02 & 0.5 & 2.5 & 2.0 \\
\hline 16 & $457.2 \times 35.0$ & 1,000 & 2.4 & 0.52 & -0.56 & -1.6 & 0.28 & 0.3 & 0.03 & 0.0 & 0.0 & 1.0 \\
\hline 17 & $457.2 \times 40.0$ & 1,000 & 0.9 & 0.20 & 0.20 & 0.5 & 0.94 & 0.5 & 0.05 & 1.0 & 0.0 & 2.0 \\
\hline 18 & $457.2 \times 45.0$ & 1,000 & 1.2 & 0.27 & 0.16 & 0.4 & 0.85 & 0.3 & 0.03 & 0.0 & 0.0 & 3.0 \\
\hline \multicolumn{3}{|c|}{ 最小 } & 0.3 & 0.05 & -0.82 & -4.3 & 0.10 & 0.1 & 0.01 & 0.0 & 0.0 & 0.0 \\
\hline \multicolumn{3}{|c|}{ 最大 } & 2.4 & 0.52 & 0.27 & 1.6 & 0.94 & 0.5 & 0.05 & 3.6 & 2.5 & 3.0 \\
\hline \multicolumn{3}{|c|}{ BS EN 10219} & \pm 10 & \pm 1 & $\pm 0.5^{* 1}$ & $\pm 10^{* 2}$ & 2.0 & 3.0 & 0.2 & $0 \sim+5$ & 4.8 & 4.8 \\
\hline
\end{tabular}

Table 5 寸法の測定結果及び寸法許容差との比較

${ }^{1} D_{n} \leqq 406.4 \mathrm{~mm}$ に対して $\pm 0.5 \mathrm{~mm}, D_{n}>406.4 \mathrm{~mm}$ に対して $\pm 2 \mathrm{~mm},{ }^{{ }^{*} 2} D_{n}>406.4 \mathrm{~mm}$ に対して $\pm 10 \%$ 
精度は良く管理されており, EN 規格を満たさないのは試験体 No.3 のみで, 厚さの誤差 $-0.72 \mathrm{~mm}$ がマイナス許容差 $-0.5 \mathrm{~mm}$ を超えて いる。もちろん,この鋼管(STK400)は JIS の許容差は満たしている。

構造用鋼管を建築鉄骨柱に普及させるには，欧州規格と同様，真 円度と真直度の数值規定が必要になってくる。真直度については従 来からの設計及び施工標準との関係で， $0.1 \%$ 以下する必要が女 り これはユーロ規格より厳しい許容差となる。真円度については, 鋼管柱どうしの継目，特にダイアフラムが無い場合に，目違いを小 さくする上で不可欠な要件となる。

\section{7. まとめ}

鉄骨ラーメン柱への適用を想定して大型構造用鋼管の材質, 残留 応力, 寸法精度を調查した。鋼材規格は一般構造用炭素鋼鋼管 STK400 と建築構造用炭素鋼鋼管 STKN490B で, 外径は 406.4 $609.6 \mathrm{~mm}$, 厚さは 16〜 45mm, 径厚比は 10～35 の範囲である。製 造方法で分類すると, 電縫鋼管, UO 鋼管, および板巻鋼管の 3 種 類である。この調査のために入手した鋼管は 18 本であるが, 製品 ままの状態に加え, それらに焼ならし熱処理 $\left(820^{\circ} \mathrm{C}\right)$ を施して成形前 の原板の状態に初期化した熱処理鋼管の合計 36 本について調べた。 主な知見は以下のとおりである。

（1）製品ままの鋼管は冷間成形の影響により応力一ひずタ曲線が 丸屋根型となるが, 熱処理鋼管では明瞭な降伏点と降伏棚が現れた。 ただし，製品ままでも応力除去焼なまし（SR 処理，620ㄷ）がされ ていた板巻鋼管では降伏棚が観察された。製品ままの鋼管は熱処理 鋼管に比べて, 降伏強さ, 引張強さ, 及び降伏比が高く, 逆に一様 伸びが小さかった。特に, 電縫鋼管では降伏強さが原板より相当高 くなっており，径厚比が小さいほどその傾向が顕著であった。

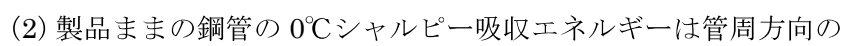
ほうが管軸方向より明らかに小さい傾向が観察された。熱処理を施 しても, その傾向は変わらなかったが, 製品ままの鋼管よりも吸収 エネルギーが全般的に上昇する傾向が見られた。鋼管の外面側と内 面側のシャルピー衝撃特性にさほど差は見られなかった。

（3）残留応力は電縫鋼管, UO 鋼管, 板巻鋼管で全く異なる様相を 呈した。電縫鋼管の管軸方向残留応力は際立って大きく, 原板の降 伏応力レベルかそれ以上の大きな值（外面が引張, 内面が圧縮）を 示した。管周方向の残留応力は相対的に小さく, 残留せん断応力は 電縫鋼管のみに観察された。熱処理鋼管では残留応力がほとんど除 去されていた。

（4）鋼管の寸法誤差はすべて JIS 規格を満たすものであったが, 国際的に厳しい公差を規定している欧州 EN 規格を満たさないもの があった。欧米で規定されている構造用鋼管の真円度と真直度は現 在の JIS では規定されていないが, これについては, 鉄骨製品とし
ての寸法精度を確保するために今後検討の余地がある。

\section{謝辞}

本研究は, 2013 年 11 月に急逝された加藤勉東京大学名誉教授の 遺志を継いで行われたものである。加藤先生から受けた薰陶に感謝 しつつ本稿を捧げたい。

\section{参考文献}

1）建設物価調查会：Web 建設物価，2014.6.

2）若林 実, 野中泰二郎, 西川一正 : 電縫鋼管の座屈に関する実験的研究, 京都大学防災研究所年報, No.12A, pp.439-462，1969.3.

3）加藤 勉, 青木博文: 電気抵抗溶接鋼管のひずみ履歷と残留応力一短柱の 圧縮試験における見掛けの応力ーひずみ関係への影響について一, 日本建 築学会論文報告集，第 230 号, pp.43-110, 1975.4 .

4) 辻 文三, 康 海偉: 電縫鋼管の材料特性, 日本建築学会構造系論文報告 集, 第 440 号, pp.85-93，1992.10.

5）仲 威雄, 加藤 勉, 湯浅 丹, 田中淳夫, 佐々木哲也 : 水平荷重を受け る鋼構造柱・はりおよびその接合部の挙動について<報告・その $2>$, 日 本建築学会論文報告集, 第 102 号, pp.37-43，1964.9.

6）高田武之, 田中 剛, 田㴊基嗣, 塩飽豊明, 大隈亮佑, 西村有司 : ノンダ イアフラム形式円形鋼管柱梁接合部の弾塑性挙動一その 2 実験結果一, 日本建築学会大会学術講演梗概集 C-1, pp.759-760, 2010.9.

7）大隈亮佑, 田中 剛, 田㴊基嗣, 高田武之, 西村有司：ノンダイアフラム 形式円形鋼管柱梁接合部の弾塑性挙動—その 4 パネル梁耐力比を因子と した十字形架構実験一, 日本建築学会大会学術講演梗概集 C-1, pp.1093-1094, 2011.8.

8）上場輝康，金谷 弘，藤原勝義，田㴊基嗣：鋼管柱・H形はり接合部の単 純模型実験一鋼管柱溶接接合部の研究 I - , 日本建築学会論文報告集, 第 322 号, pp.44-51, 1982.12 .

9）付 功義, 森田耕次 : コンクリート充填円形鋼管柱 - 鉄骨梁フランジ接合 部の局部引張耐力に関する研究, 日本建築学会構造系論文集, 第 504 号, pp.119-125，1998.2.

10）伊藤豪城, 付 功義, 永田匡宏, 中村秀司, 森田耕次 : コンクリート充 填円形鋼管柱 - 鉄骨梁接合部の力学的挙動に関する研究, その 1 研究計 画と実験結果, 日本建築学会大会学術講演梗概集 C-1, pp.831-832, 1995.8 . 11）桑村 仁：建築の力学－弾性論とその応用－（第 9 章永゙り），技報堂 出版, 2001.4.

12）日本規格協会：JIS ハンドブック 2-鉄鋼 II , 2014.1.

13) British Standards Institution: Hot Finished Structural Hollow Sections of Non-Alloy and Fine Grain Steels - Part 2: Tolerances, dimensions and sectional properties (BS EN 10210-2), 2006.

14) British Standards Institution: Cold Formed Welded Structural Hollow Sections of Non-Alloy and Fine Grain Steels - Part 2: Tolerances, dimensions and sectional properties (BS EN 10219-2), 2006.

15) ASTM International: Annual Book of ASTM Standards, Section 1/Iron and Steel Products, Volume 01.01/Steel-Piping, Tubing, Fittings, 2014.

16) 日本建築学会: 建築工事標準仕様書 JASS 6 鉄骨工事(第 9 版), 2012.5. 17）日本建築センター：2008 年版冷間成形角形鋼管設計・施エマニュアル, 全国官報販売協同組合，2008.12. 


\section{Hitoshi KUWAMURA*}

* Prof., Dept. of Architecture, School of Engineering, The University of Tokyo, Ph. D.

Mechanical properties, residual stresses and dimensional accuracies of heavy-section steel tubes of circular hollow section (CHS), that are presumed to be utilized in building columns, were investigated. They are designated as STK400 and STKN490B in Japanese Industrial Standards (JIS). The dimensions of the examined tubes are ranging 406.4 to $609.6 \mathrm{~mm}$ in diameter, 16 to $45 \mathrm{~mm}$ in thickness, and 10 to 35 in diameter-to-thickness ratio, as scheduled in Table 2 and plotted in Fig. 2. They are manufactured by one of three different cold-forming processes named as roll-forming with electric resistance welding (ERW), UO-forming with submerged arc welding (SAW), and Bending-roll forming with SAW. The sample number was 18 as delivered, and half cuts of them were normalized at $820^{\circ} \mathrm{C}$ in furnace in order to identify the properties of original steels before their cold-forming processes.

The stress-strain curves in longitudinal direction of as-delivered tubes except stress-relieved Bending-roll tubes show the round-roof type due to the cold-forming effect, while those of normalized tubes show an apparent yield point followed by a yield plateau as exemplified in Fig. 3. As-delivered tubes exhibited higher yield strength, tensile strength and yield ratio, but less uniform elongation than their correspondent normalized ones, which are summarized in Table 3. Especially, the elevation of yield strength of ERW tubes to the original hot-rolled steels is significant in the way that the elevation is escalated with the decrease of diameter-to-thickness ratio as shown in Fig. 4.

Charpy impact test was performed at $0^{\circ} \mathrm{C}$ for V-notch specimens extracted from the tubes as illustrated in Fig. 6 . Charpy absorbed energy of as-delivered tubes is smaller in circumferential direction than in longitudinal direction as observed in Figs. 7 and 8, the tendency of which is not altered in the normalized tubes. This suggests that the mode-L fracture in Fig. 5 cannot be neglected. The absorbed energy of normalized tubes is generally greater than that of as-delivered as shown in Fig. 9. The differences of absorbed energy between outer and inner surfaces of the tubes are not noticeable.

Residual stresses were evaluated by means of measuring deformations of pieces cut from the tubes so that the deformations come from the release of residual strains contained in the material as illustrated in Figs.11, 12, and 13. Residual stresses in ERW tubes in their longitudinal direction are extremely large in comparison with UO and Bending-roll tubes as shown in Fig. 14 such that the outer surface is in tension and the inner surface is in compression. Residual stresses in the circumferential direction are relatively smaller as shown in Fig. 15. Residual shearing stresses associated with residual torque confined during the process of cold-forming are observed only in ERW tubes as shown in Fig. 16. All types of residual stresses in the normalized tubes are negligible.

Dimensional deviations from nominal or specified sizes are measured in the scope of JIS, European Standards (EN) and American Standards (ASTM), whose tolerances are compared in Table 4. The dimensional errors of the examined tubes, as summarized in Table 5, are small enough to satisfy the tolerances specified in JIS, but not always meet EN. The straightness and out-of-roundness specified in EN and partly in ASTM should be specified in JIS in order to qualify the fabrication of tubular columns in buildings.

（2014年 9 月 1 日原稿受理，2014年11月 6 日採用決定） 